\title{
TRADITIONS OF NATIVITY DRAMA WITHIN THE OPERA ARTS OF UKRAINE
}

\author{
Daryna Lukava \\ National Academy of Culture and Arts Management \\ 9 Lavrsk str., Kyiv, Ukraine, 01015 \\ korlepik73@gmail.com
}

\section{Abstract}

The article explores the ways of development of Ukrainian nativity drama - a genre of musical art that provides an opportunity to recreate the elusive breath of time, to learn not only about the world around but also the prospects for its preservation in Ukrainian culture. For the formation and development of the national musical culture of Ukraine, the traditions of Ukrainian nativity drama, the precondition of which was the folk music of national-historical orientation, became especially important. Besides, the folklore basis contributed to the formation of some professional genres, including opera and instrumental plays.

The object of the research is the nativity drama within the opera art of Ukraine.

The purpose of the article is to identify the features of the nativity scene as a musical and dramatic art form, which is an original monument of Ukrainian culture.

It should be noted, that the nativity scene, especially the images of the second act, the type of its drama, had an impact on the development of Ukrainian musical and dramatic theater even in the XIX century. The mentioned influence was manifested, in particular, in the musical drama "Chornomorets", "Natalka Poltavka" by Lysenko, where folk song and dance are an integral part of the action and are a means of characterizing individual characters and dramatic situations. Some features of the character of Zaporozhets from the nativity scene were developed in the image of Karas from S. Gulak-Artemovsky's opera “Zaporozhets za Dynayem”. Ukrainian music and drama art with its sources are associated with the ancient East Slavic agricultural and family holidays, games, dances, in which the element of dramatization played an important role since ancient times. Christmas games with costumes, Maslenitsa farewells, spring round dances, harvest festivals, autumn-winter round dances, and weddings became a rich source for the development of musical and theatrical art of the Ukrainian people in the XV-XVI centuries. To sum up, we can conclude that for the formation and development of the national musical culture of Ukraine in the XIX century, the Ukrainian opera became especially important, the precondition of the one was the folk music of national-historical orientation. Also, the folklore foundations, in particular the nativity scene, served to form professional genres including opera and instrumental plays.

The study can be applied to prepare students and graduates in the field of Historical Sciences, Musicology, and Culturology.

The significance and influence of nativity drama on the opera art of Ukraine have been studied, where the traditions of Ukrainian nativity scene, the precondition of which was the folk music of national-historical orientation, have been singled out.

The study can be the basis for further study of the Ukrainian nativity drama of the XX-XXI centuries.

Keywords: nativity scene, drama, opera, folklore, musical culture.

DOI: $10.21303 / 2504-5571.2020 .001564$

\section{Introduction}

The object of research is the nativity drama in the opera art of Ukraine

Ukrainian musical culture of the second half of the XVIII century is called the "golden age of Ukrainian music." During this period the spiritual choral creativity reaches classical peaks. In addition, there has been significant progress in the field of secular music genres, such as opera, symphony, concert, and more. 
The purpose of the article is to identify the features of the nativity scene as a musical and dramatic art form, which is an original monument of Ukrainian culture.

It should be noted, that instrumental and vocal-choral music became inseparable components of the theatrical culture of that time, in particular the nativity scene. In the theater, professional music clearly showed the style - the nativity scene.

Origins, evolution, some aspects of the nativity scene were studied in such works as P. Zhitetsky's “Little Russian Nativity Scene or Nativity Scene Christmas Drama” (1882), M. Petrov's "Ancient South Russian Theater and in particular the Nativity Scene" (1882), Peretz "Puppet Theater in Russia: a historical essay" (1895) and "To the history of the nativity drama" (1908), I. Franko "To the history of the Ukrainian nativity scene of the XVIII century" (1906), E. Markovsky "Ukrainian Nativity Scene: Explorations and Texts" (1929), O. Kisel "On the Origin of the Ukrainian Nativity Scene” (1915), L. Kurbas "On the Christmas Nativity Scene” (1918), O. Biletsky "Ancient theater in Little Russia and the beginnings of theater in folklife" (1923). A prominent place is given to the nativity scene in the research of modern scientists, in particular, in the works of O. Kurochkin and A. Ponomarev. The research of a musicologist M. Kopytsa "Interaction of Arts in the Ukrainian Nativity Scene" is relevant, the nativity scene is defined as a musical and dramatic art form, an original monument of Ukrainian culture, which focuses on all kinds of Ukrainian art - theater, painting, choreography, drama, poetry, music [1]. The researcher substantiates the need for a comprehensive study of the nativity scene, as "the idea of internal interdependence, cementing the nature of relationships and interrelationships of related arts while taking into account methodological parameters, which allow to explore the object of art, to proceed to the laws of artistic thinking" [2].

The period of origin of the nativity scene is still not clear, because there are no texts of nativity scenes. It is known, that traveling actors-amateurs went during the Christmas holidays with a nativity scene to isolated farmsteads and villages, went to manors and Cossack settlements, thus earning crust. The nativity scene took place in a large wooden box (chest), it was divided into two (sometimes three) floors. The puppets, which were fixed with wires, were led by actors. The design of the box (chest) was not accidental, because it had certain plot lines, which were played out in two directions - religious and folk [3, 4].

The first documentary evidence of the Ukrainian nativity scene is contained in the income books of the Lviv Brotherhood, dated by July 14, 1666, which states what funds were allocated to the carpenter to build the nativity scene and the painter, who provided its decoration [5, p. 1022-1023]. Unfortunately, no authentic texts of nativity dramas of the XVII century were found. Their content can only be guessed from the texts of the second half of the XVIII-XIX centuries. Probably, the texts of Sokyrynsky, Kupyansky, Baturynsky, Khorolsky nativity scenes contain fragments, motives, plot moves, etc., which will allow reconstructing earlier samples.

In our opinion, the baroque character of the nativity scene is obvious, which allows connecting the creation of its classical form with the period of the national and cultural revival of the XVII-XVIII centuries [6]. No features, linking the nativity scene to earlier historical periods, have been identified. The nativity scene, with which the carolers went, was small in size, shaped like a box without a front wall, divided into two tiers. Despite the apparent simplicity, design, manufacture, and decoration of nativity scene props required remarkable artistic skill and artistic taste. The intricately decorated nativity boxes and skillfully painted dolls were real masterpieces of folk decorative art.

This design of the chest is not accidental: it corresponded to the peculiarities of the plot, which unfolded along with two storylines - religious and folk. On the upper, "heavenly" floor, a Christian drama-mystery about the birth of Christ by the Virgin Mary was played out, angelic choirs, chants, and carols were sung.

On the lower, "earthly" - stood the throne of King Herod, acted Death, the Devil, and other characters. In the second, interlude action, comic scenes and dialogues from Ukrainian life were performed, folk songs and dances were performed, and "triple music" was played. In the end, the main character appeared - the People's Defender - a brave Zaporozhets. The doll was made taller than all the others and dressed in a bright Ukrainian costume. Zaporozhets defeated everyone and sang a decisive epic song "It will not be better, but it will not be better, as in our 
country and Ukraine." Poles danced Krakowiak, a Russian soldier, "Muscovite” - Kamarin, Ukrainians - Grandfather and Grandmother sang "Oh, under the cherry, under the cherry" and danced an inflammatory Cossack. In this way, the music emotionally enhanced the national identity of the images.

O. Kurochkin draws attention, in particular, to the carving skill of the manger manufacturing, in front of which the performances of the "living nativity scene" took place, as well as to the lighting effects, achieved by minimal means: the front wall, sealed with paper, then became a kind of screen "[7, p. 78].

One of the first that gained popularity, in Western Ukraine (Galicia, Bukovina, Transcarpathia) was, so to speak, "living" nativity scene, in which people-actors played. In general, the nativity drama has become a favorite artistic spectacle of the masses and has become a prerequisite for Ukrainian democratic theater [8].

Aim of research. The study intends to identify the features of the nativity drama as a musical and dramatic art form, which is an original achievement of Ukrainian culture.

\section{Materials and Methods}

The methodology was based on the application of general scientific methods and approaches to solve problems: comparative analysis served to identify the originality of nativity drama; musicological analysis pointed the expediency of the establishment and development of Ukrainian nativity drama for the formation and prospects of its preservation within Ukrainian musical culture.

\section{Result}

As already noted, in the late XVI - early XVIII centuries in Ukraine, a folk musical puppet theater, known as the Nativity Scene, emerged. The play was performed on a specially adapted stage with traditional scenery and costumes. The nativity scene is considered to be one of the earliest forms of theatrical and musical spectacle, due to which new forms of secular vocal music emerged - edging and solo song with instrumental accompaniment.

That time, the famous music for the nativity drama was written by Grigory Skovoroda (1722-1794). This is the edging of "Dear Shepherds", which was part of the nativity drama and reflected in other songs by G. Skovoroda, which have survived to our time in the oral tradition.

It should be noted, that the nativity scene, in particular the images of the second act, as well as the genre of its drama, had an impact on the development of Ukrainian musical and dramatic theater in the XIX century; the mentioned issue is reflected, in particular, in the musical drama "Chernomorets", "Natalka Poltavka", where folk songs and melts are an integral part of the action, as well as an expressive means of characterization of some roles and dramatic plot. For example, certain features of the character of Zaporozhets from the nativity scene were reflected in the image of Karas from the opera "Zaporozhets za Dynayem” by S. Gulak-Artemovsky [9].

The combination of folklore and professional, festive-ritual and household led to the crystallization of the nativity scene as a universal art form, which is used and developed in our time by artists of various arts. The artistic potential of the nativity scene is relevant today, at the same time the nativity scene, as part of the Christmas and New Year rituals, is actively revived, in particular, in the traditional forms of puppet theater and "living" nativity scene.

The nativity scene is an extremely complex artistic phenomenon. Its two-storey architecture, combining the sacred "top" and the profane "bottom", eternal and transient, tragic and comic, turned the nativity scene into a model of the Ukrainian world. The nativity scene synthesizes all kinds of Ukrainian art - drama, poetry, theater, music, choreography, decorative arts. While implementing folklore, the nativity scene became an integral part of the calendar Christmas and New Year rituals of Ukrainians. The combination of folklore and professional, festive-ritual and household led to the crystallization of the nativity scene as a universal art form, which is used and developed in our time by artists of various arts. The artistic potential of the nativity scene is actualized in our time while proving its inexhaustibility, first of all - in various genres of literature - poetry, prose, drama. At the same time, the nativity scene, as part of the Christmas and New Year rituals, is actively revived in the traditional forms of puppet theater and "living nativity scene" [9]. 
We have received music for the nativity drama, written by Hryhoriy Skovoroda (1722-1794). This is the edging "Dear Shepherds". The edging was part of the nativity drama that is associated with other songs by Skovoroda, which are preserved, as a rule, in the oral tradition.

The existence of a musical notation, indicating the instruments, intended to play the role of accompaniment to vocal voices, in general, the dialogic nature of this vocal number (questions and answers), may indicate that the whole parable was intended for theatrical performance with music. The melody is close to the intonations of folk songs and dance music of European origin. In particular, there are connections with the rhythmic intonations of carols, minuets, waltzes, which then began to spread in urban life.

One of the features of the ancient theater is its ability to revive and develop at the turning points of Ukrainian history. Thus, in the second half of the nineteenth century the motives of the traditional nativity scene found a talented artistic rethinking in P. Kulish's drama "Heroic Darkness"; In 1907, L. Starytska-Chernyakhivska turned to the form of a nativity scene, publishing in the Rada newspaper under the pseudonym Staren'ka Mukha an "ancient mystery on new topics", called "Nativity Scene"; in 1918 L. Kurbas wrote an article about the Christmas nativity scene, and in 1919 he created the play "The Christmas Nativity Scene"; a sharp discussion about the fate of the nativity theater broke out in the 1920s, the participants of which - O. Vedmitsky, Y. Stolych, and others testified to the relevance of the nativity scene in the new historical conditions. At the same time, A. Lyubchenko's prose work "Vertep" was published. In the late '60s of the twentieth century, a philosophical drama, called "Nativity Scene", was created by V. Shevchuk. The appearance of such poetic works as I. Kalynets's “Nativity Scene”, G. Chubay’s "Nativity Scene”, D. Pavlychko's "Nativity Scene”, V. Bazylevsky’s "Nativity Scene”, V. Kordun's "Ukrainian Nativity Scene”, V. Osadchy's "Ancient Nativity Scene", "Nativity Drama” by D. Kremen testifies to the actualization of the nativity scene, invented in the XVII century in terms of our time, which M. Sulima did not accidentally call "the most universal art form" $[10,11]$.

The research proves that the Ukrainian opera acquired special significance in the formation and development of the national musical culture of Ukraine in the XIX century, the precondition of which was the folk music of national-historical direction. It should be noted, that the folklore foundations, in particular the nativity scene, served to form professional genres, including opera and instrumental plays.

\section{Conclusions}

It should be noted, that the nativity scene, especially the images of the second act, the type of its drama, had an impact on the development of Ukrainian musical and dramatic theater even in the XIX century. This influence was manifested, in particular, in the musical drama "Chornomorets", "Natalka Poltavka" by Lysenko, where folk song and dance are an integral part of the action and are a means of distinguishing individual characters and dramatic situations. Some features of the character of Zaporozhets from the nativity scene were developed in the image of Karas from S. Gulak-Artemovsky’s opera “Zaporozhets za Dynayem”.

Ukrainian music and drama art with its sources are associated with the ancient East Slavic agricultural and family holidays, games, dances, in which elements of dramatization played the important role since ancient times. Christmas games with costumes, Maslenitsa farewells, spring round dances, harvest festivals, autumn-winter round dances, and weddings became a rich source for the development of musical and theatrical art of the Ukrainian people in the XV-XVI centuries.

To sum up, we can conclude that, the Ukrainian opera became especially important for the formation and development of the national musical culture of Ukraine in the XIX century, the precondition of the one was the folk music of national-historical orientation. Also, the folklore foundations, in particular the nativity scene, served to form professional genres, including opera and instrumental plays.

\section{References}

[1] Izvarina, O. M. (2011). Ukrainske operne mystetstvo v istorii natsionalnoi khudozhnoi kultury druhoi polovyny XIX - pershoi tretyny XX stolittia: Kyiv: NAKKKi, 236. 
[2] Khlystun, O. S. (2012). Ukrainskyi rizdvianyi vertep yak universalna mystetska forma. Ukrainska kultura: mynule, suchasne, shliakhy rozvytku, 18 (2), 37-41. Available at: http://nbuv.gov.ua/UJRN/Uk_msshr_2012_18\%282\%29_10

[3] Derzhavnyi muzei teatralnoho, muzychnoho i kinomystetstva Ukrainy. R. 4899. Arkhiv «Vertep».

[4] Derzhavnyi muzei teatralnoho, muzychnoho i kinomystetstva Ukrainy. R. 10818. Arkhiv «Vertep».

[5] Pylypchuk, R. Ya. (2001). Teatr v Ukraini. Istoriia ukrainskoi kultury. Kyiv: Naukova dumka, 3, 1006-1028.

[6] Genkin, A. A., Kalashnyk, M. P., Loshkov, Yu. I., Ovcharenko, T. S., Ovchynnikova, A. P., Uvarova, T. I. (2020). Culture and art: discursive dimension in the early XXI century. Lviv-Toruń: Liha-Pres, 136.

[7] Kurochkin, O. V. (1978). Novorichni sviata ukraintsiv: Tradytsii ta suchasnist. Kyiv: Naukova Dumka, 191.

[8] Ukrainska khudozhnia kultura druhoi polovyny XVIII st. Kultura (2010). Available at: https://ru.osvita.ua/vnz/reports/culture/10910/ Last accessed: 09.2020

[9] Serdiuk, O. V., Umanets, O. V., Sliusarenko, T. O. (2002). Ukrainska muzychna kultura: vid dzherel do suchasnosti. Kharkiv: Osnova, 400

[10] Istoriia ukrainskoi kultury (Ukrainska kultura XIII - pershoi polovyny XVII stolit). Vol. 2. Available at: http://izbornyk.org. ua/istkult2/ikult2.htm Last accessed: 10.2020

[11] Ukrainskyi vertep: Vertep u drami, prozi ta poezii XIX-XX stolit (2010). Kyiv: Dnipro, 608. 